\title{
Cross-cultural discussions in a 3D virtual environment and their affordances for learners' motivation and foreign language discussion skills
}

\author{
Kristi Jauregi $^{1}$, Leena Kuure ${ }^{2}$, Pim Bastian ${ }^{3}$, \\ Dennis Reinhardt ${ }^{4}$, and Tuomo Koivisto ${ }^{5}$
}

\begin{abstract}
Within the European TILA ${ }^{6}$ project a case study was carried out where pupils from schools in Finland and the Netherlands engaged in debating sessions using the 3D virtual world of OpenSim once a week for a period of 5 weeks. The case study had two main objectives: (1) to study the impact that the discussion tasks undertaken in a virtual environment have on the discussion skills and motivations of high school pupils, and (2) to explore how the presence of a peer from a different culture might influence the discussions and pupils' engagement. The discussion tasks in virtual worlds were very much appreciated by the participants. Telecollaboration, or the possibility to interact with pupils across borders, was found to have an additional motivational effect on pupils. Even if participants with varying linguistic resources may successfully work together in many authentic situations, telecollaboration in a Lingua Franca with focus on debates, for example, requires careful matching of the participants according to their proficiency levels. Otherwise the experience might increase anxiety levels of the less proficient pupils.
\end{abstract}

Keywords: telecollaboration, multimodal interaction, virtual worlds, intercultural communication, discussion skills.

1. Utrecht University \& Fontys University of Applied Sciences, Netherlands; k.jauregi@uu.nl

2. University of Oulu, Finland; leena.kuure@oulu.fi

3. Utrecht University, Netherlands; p.bastian@students.uu.nl

4. Utrecht University, Netherlands; d.reinhardt@students.uu.nl

5. University of Oulu, Finland; tuomo.koivisto@eduouka.fi

6. Telecollaboration for Intercultural Language Acquisition: www.tilaproject.eu

How to cite this article: Jauregi, K., Kuure, L., Bastian, P., Reinhardt, D., \& Koivisto, T. (2015). Cross-cultural discussions in a $3 \mathrm{D}$ virtual environment and their affordances for learners' motivation and foreign language discussion skills. In F. Helm, L. Bradley, M. Guarda, \& S. Thouësny (Eds), Critical CALL - Proceedings of the 2015 EUROCALL Conference, Padova, Italy (pp. 274-280). Dublin: Research-publishing.net. http://dx.doi.org/10.14705/rpnet.2015.000345 


\section{Introduction}

Telecollaboration introduces an important dimension to foreign language learning, as it puts authentic interaction with peers in an intercultural setting at the center of the innovative pedagogical agenda. In this sense, language learning is not just about learning grammar and words and filling in gaps; it is about activating and using language to communicate with real people, in our case, across borders, and come to know who they are, how they live, what they think and undertaking activities together while reflecting about intercultural concerns. Teachers can resort to different internet applications to organise telecollaboration sessions. One of the appealing environments are $3 \mathrm{D}$ virtual worlds because of the rich multimodal communication affordances they offer and the actions they allow for in different scenarios.

This paper introduces a case study which focuses on telecollaboration among pupils from Dutch and Finnish schools. The aim was twofold: to shed light on the impact of the discussion tasks undertaken in a virtual environment on the participants' discussion skills and motivations, and to explore how the intercultural aspect might influence the discussions and pupils' engagement.

\section{Data and methodology}

The 18 participants came from two schools, one in the Netherlands and another in Finland. The pupils were between 15-18 years of age and their English skills were roughly at level B2 (CEFR). The pupils were divided into three groups. The first group of participants consisted of 6 Dutch pupils who carried out the same tasks in the virtual world but with classmates and was used as a control group (Dutch C). The other two groups consisted of 6 pupils each; 3 Finnish and 3 Dutch pupils.

All pupils participated in a specifically designed discussion task series, with 5 tasks in total and a tutorial at the start. Diverse types of data were gathered and analysed: pre- and post- tests on discussion ability, surveys, recorded interactions and interviews. The analysis focused on the impact of the role tasks (GonzálezLloret \& Ortega, 2014; Jauregi et al., 2011) and the presence of peers from another culture on the pupils' discussion skills, engagement and motivation (Geer, 2001; Deutschmann \& Panichi, 2009; Jauregi et al., 2011). Furthermore, multimodal aspects of actions and interactions in the virtual environment were examined (Jones, 2005; Norris, 2011). Ethical issues were considered carefully including informed consent and handling of data. 


\section{Findings}

In the following, the main findings of the study will be discussed.

\subsection{The development of discussion skills}

As we can see in Figure 1 there was a clear difference in the pupils' proficiency level prior to starting the project. Overall the Finnish pupils had a lower oral proficiency mean value (3.7) than the Dutch pupils, both the control group (6.4) and the $\mathrm{ICC}^{7}$ group (7.7).

Differences between pre- and post-test values show that the three groups of pupils increased their discussion skills. Growth was higher for the Finnish and the Dutch control group (average improvement 0.7) than for the Dutch ICC group (0.3).

Figure 1. Average pre- and post-test results per group (Finnish and Dutch pupils interacting cross-culturally \& Dutch Control group)

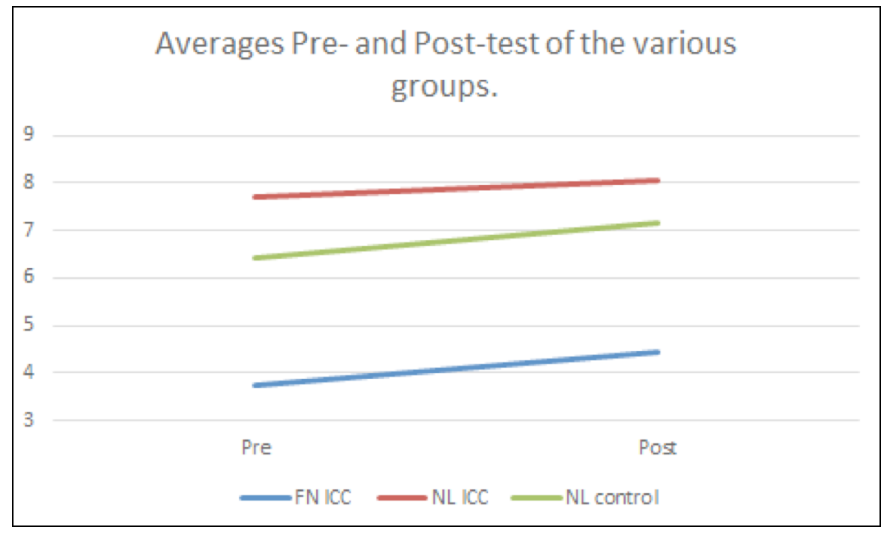

\subsection{The pupils' engagement and motivation}

Pupils were positive about the 3D virtual environment used during the project, although they reported having experienced technological problems with sound. Interestingly, pupils felt very comfortable and would not have preferred to carry out the discussion tasks face-to-face (see Table 1).

7. Dutch ICC group: those interacting with the Finnish pupils. 
Table 1. Pupils' reactions to the use of virtual worlds (5 point Likert-scale. 1: strongly disagree; 5 strongly agree). *Dutch $\mathrm{C}$ (control group, that carried out the tasks with classmates in the virtual world)

\begin{tabular}{|c|c|c|c|c|c|c|}
\hline \multirow[t]{2}{*}{ Items } & \multicolumn{2}{|c|}{ Finnish } & \multicolumn{2}{|c|}{ Dutch } & \multicolumn{2}{|c|}{ Dutch $(C) *$} \\
\hline & $\begin{array}{l}\text { Mea } \\
\mathrm{n}\end{array}$ & $\begin{array}{r}\text { SDe } \\
\mathrm{v}\end{array}$ & $\begin{array}{r}\text { Mea } \\
\mathrm{n}\end{array}$ & SDev & $\begin{array}{r}\text { Mea } \\
\mathrm{n}\end{array}$ & $\begin{array}{r}\text { SDe } \\
\mathrm{v}\end{array}$ \\
\hline OpenSim is useful as a tool. & 3.8 & 0.4 & 3.8 & 0.8 & 4.0 & 0.0 \\
\hline OpenSim worked well during the experiment. & 3.0 & 1.1 & 3.2 & 1.0 & 3.2 & 0.8 \\
\hline $\begin{array}{l}\text { The audio worked during all the sessions: I could hear other } \\
\text { people well. }\end{array}$ & 2.8 & 0.8 & 2.5 & 1.4 & 2.6 & 0.5 \\
\hline $\begin{array}{l}\text { I felt comfortable in OpenSim: I could move and act the way I } \\
\text { wanted. }\end{array}$ & 3.8 & 0.8 & 4.7 & 0.5 & 4.2 & 0.4 \\
\hline $\begin{array}{l}\text { If you had had the possibility to carry out the tasks face-to- } \\
\text { face, would you have preferred this option to using OpenSim? }\end{array}$ & 1.7 & 1.8 & 1.8 & 0.8 & 2.8 & 0.4 \\
\hline
\end{tabular}

As to the anxiety and self-efficacy issues, when comparing pre- and post questionnaires, a difference was detected among the Dutch and the Finnish pupils (Table 2). The Dutch pupils became less anxious and more confident when speaking in English, while the opposite was found for the Finnish pupils. This might well be due to the difference in speaking skills as Dutch pupils had a high B2 proficiency level and the Finnish pupils a B1 - low B2 level.

Table 2. Anxiety and self-efficacy values comparing pre- and post- questionnaires. (FN: Finnish group. NL: Dutch group. ${ }^{*} \mathrm{C}$ (control group)

\begin{tabular}{|c|c|c|c|c|c|c|c|c|c|c|}
\hline \multirow{2}{*}{$\begin{array}{l}\text { Item } \\
\text { Anxiety/self-efficacy }\end{array}$} & \multicolumn{2}{|c|}{ Pre-FN } & \multicolumn{2}{|c|}{ Post-FN } & \multicolumn{2}{|c|}{ Pre-NL } & \multicolumn{2}{|c|}{ Post-NL } & \multicolumn{2}{|c|}{$\begin{array}{c}\text { Post-NL } \\
\left.C^{*}\right)\end{array}$} \\
\hline & $\begin{array}{r}\text { Mea } \\
\mathrm{n}\end{array}$ & $\begin{array}{l}\mathrm{S} \\
\mathrm{D}\end{array}$ & $\begin{array}{r}\text { Mea } \\
\mathrm{n}\end{array}$ & $\begin{array}{l}\mathrm{S} \\
\mathrm{D}\end{array}$ & $\begin{array}{r}\text { Mea } \\
n\end{array}$ & $\begin{array}{r}S \\
D\end{array}$ & $\begin{array}{r}\text { Mea } \\
\mathrm{n}\end{array}$ & $\mathrm{SD}$ & $\begin{array}{r}\text { Mea } \\
\mathrm{n}\end{array}$ & $\mathrm{SD}$ \\
\hline $\begin{array}{l}\text { I feel uneasy whenever I have to speak } \\
\text { English. }\end{array}$ & 1.5 & $\begin{array}{c}0 . \\
5\end{array}$ & 2.2 & $\begin{array}{c}0 . \\
8\end{array}$ & 2.8 & 1.2 & 1.5 & 0.5 & 1.6 & 0.5 \\
\hline $\begin{array}{l}\text { I am confident about my English speaking } \\
\text { skills. }\end{array}$ & 3.5 & $\begin{array}{c}0 . \\
8\end{array}$ & 3.0 & $\begin{array}{r}1 . \\
1\end{array}$ & 3.1 & 1.1 & 3.7 & 1.5 & 3.4 & 0.5 \\
\hline $\begin{array}{l}\text { I am confident about my English } \\
\text { discussion skills.. }\end{array}$ & 3.7 & $\begin{array}{c}0 . \\
5\end{array}$ & 3.3 & $\begin{array}{c}0 . \\
8\end{array}$ & 2.5 & 1.2 & 35 & 1.4 & 3.0 & 1.0 \\
\hline $\begin{array}{l}\text { I feel very uneasy whenever I make a } \\
\text { mistake while speaking English. }\end{array}$ & 2.3 & $\begin{array}{r}0 . \\
5\end{array}$ & 2.5 & $\begin{array}{r}1 . \\
0\end{array}$ & 3.1 & 1.3 & 2.5 & 1.4 & 2.6 & 0.9 \\
\hline $\begin{array}{l}\text { I feel very uneasy whenever I do not } \\
\text { understand what is being said in English }\end{array}$ & 3.0 & $\begin{array}{c}0 . \\
6\end{array}$ & 2.8 & $\begin{array}{c}1 . \\
2\end{array}$ & 2.3 & 1.3 & 1.8 & 1.2 & 2.2 & 0.8 \\
\hline $\begin{array}{l}\text { I feel more at ease when I cannot be seen } \\
\text { (on a webcam) while communicating. }\end{array}$ & 2.3 & $\begin{array}{c}0 . \\
5\end{array}$ & 3.0 & $\begin{array}{c}0 . \\
9\end{array}$ & 2.8 & 1.5 & 3.7 & 1.0 & 3.2 & 1.1 \\
\hline
\end{tabular}

Pupils enjoyed the discussion tasks (Table 3). They were felt to be useful for language learning and development of discussion skills. Dutch pupils particularly enjoyed the last two tasks (Police station \& Courthouse) while the Finnish pupils 
preferred the first two ones. The Finnish pupils also found these tasks to be more demanding than the tasks they usually carry out in the classroom setting. The Dutch control group also enjoyed the discussion tasks.

Table 3. Pupils' evaluation of tasks

\begin{tabular}{|c|c|c|c|c|c|c|}
\hline Items & \multicolumn{2}{|c|}{ Finnish } & \multicolumn{2}{|c|}{ Dutch } & \multicolumn{2}{|c|}{ Dutch (C) } \\
\hline I enjoyed participating in the following tasks: & Mean & $\begin{array}{r}\mathrm{SDe} \\
\mathrm{v}\end{array}$ & Mean & SDev & Mean & $\begin{array}{r}\text { SDe } \\
\mathrm{V}\end{array}$ \\
\hline Task 1: Campsite & 3.8 & 0.4 & 3.3 & 1.5 & 3.4 & 0.9 \\
\hline Task 2: Church & 3.8 & 0.4 & 2.7 & 1.2 & 3.8 & 0.4 \\
\hline Task 3: Airport/Vacation & 3.7 & 0.5 & 3.3 & 0.8 & 2.6 & 0.9 \\
\hline Task 4: Police station & 3.3 & 0.5 & 4.2 & 0.4 & 4.0 & 0.7 \\
\hline Task 5: Courthouse & 3.2 & 1.2 & 4.0 & 0.9 & 4.6 & 0.5 \\
\hline $\begin{array}{l}\text { The tasks were harder than assignments in my English } \\
\text { class. }\end{array}$ & 4.0 & 1.1 & 2.0 & 0.6 & 2.0 & 1.0 \\
\hline
\end{tabular}

Both Dutch and Finnish pupils felt they had learned about the other culture and found it quite interesting to interact with pupils with a different cultural background (Table 4).

Table 4. Intercultural gains

\begin{tabular}{|c|c|c|c|c|}
\hline \multirow[t]{2}{*}{ Items } & \multicolumn{2}{|c|}{ Finnish } & \multicolumn{2}{|c|}{ Dutch } \\
\hline & Mean & $\begin{array}{r}\mathrm{SDe} \\
\mathrm{V}\end{array}$ & $\begin{array}{r}\text { Mea } \\
\mathrm{n}\end{array}$ & SDev \\
\hline $\begin{array}{l}\text { I knew a lot about Finnish/Dutch culture before } \\
\text { starting the course. }\end{array}$ & 2.5 & 0.8 & 1.7 & 1.2 \\
\hline $\begin{array}{l}\text { I know much more about Finnish/Dutch culture now } \\
\text { that I finished the course. }\end{array}$ & 3.8 & 0.4 & 3.0 & 1.3 \\
\hline $\begin{array}{l}\text { It was interesting for me to communicate with the } \\
\text { Finnish/Dutch pupils. }\end{array}$ & 3.3 & 0.8 & 3.7 & 1.5 \\
\hline
\end{tabular}

Finally, pupils would like to continue participating in these kinds of projects or would recommend other peers to do so. The values are noticeably higher by the Dutch pupils (Table 5). It might be due to different reasons: the Finnish pupils being younger, having a slightly lower proficiency level and different interaction patterns in Dutch and Finnish, which could all be influencing the way Finnish and Dutch pupils interact. Dutch pupils were observed to take continuously the floor to discuss task issues, while Finnish pupils adopted a more receptive role. In the Dutch control group discussions were more symmetrical. 
Table 5. Overall project evaluation

\begin{tabular}{|l|r|r|r|r|r|r|}
\hline Items & \multicolumn{2}{|c|}{ Finnish } & \multicolumn{2}{c|}{ Dutch } & \multicolumn{2}{c|}{ Dutch (C) } \\
\hline How do you value the project? & Mean & SDev & Mean & SDev & Mean & SDev \\
\hline $\begin{array}{l}\text { I would like to participate in a similar } \\
\text { project again in the future }\end{array}$ & 3.2 & 1.0 & 4.0 & 0.0 & 4.6 & 0.5 \\
\hline $\begin{array}{l}\text { I would recommend other pupils to } \\
\text { participate in a similar project. }\end{array}$ & 3.2 & 1.0 & 4.0 & 0.0 & 4.8 & 0.4 \\
\hline
\end{tabular}

\subsection{Multimodal (inter)actions}

An initial viewing of the data from a multimodal perspective highlighted the participants' involvement in social actions across multiple timescales and places, characterised as layered simultaneity (Blommaert, 2005). This complexity was orchestrated through attention structures (Jones, 2005; Norris, 2011) afforded by the virtual world and created during the social activities at hand. As in gaming events, time was spent familiarising with the environment, getting organised and sorting out problems, beside the discussion tasks themselves. These "meta events" provide the participants with constant opportunities for learning.

\section{Conclusion}

Pupils improved their discussion skills and enjoyed the discussion experience in 3D virtual worlds. Even the control group, who did not have the opportunity to collaborate with pupils abroad, was very positive about the experience.

Based on the results of this case study we recommend teachers willing to integrate oral telecollaboration practices in Lingua Franca in their teaching to pair pupils having similar proficiency levels to reduce anxiety of those having lower proficiency levels.

\section{Acknowledgements}

We thank the pupils and their teachers in the participating schools as well as the support staff from the TILA project for their important contribution to the study.

\section{References}

Blommaert, J. (2005). Discourse: a critical introduction. Cambridge: Cambridge University Press. doi:10.1017/CBO9780511610295 
Kristi Jauregi, Leena Kuure, Pim Bastian, Dennis Reinhardt, and Tuomo Koivisto

Deutschmann, M., \& Panichi, L. (2009). Designing oral participation in Second Life - a comparative study of two language proficiency courses. ReCALL, 21(2), 206-226. doi:10.1017/S0958344009000196

Geer, P. van der (2001). De Kunst van het Debat (2nd ed.). Den Haag: Sdu Uitgevers.

González-Lloret, M., \& Ortega, L. (Eds.). (2014). Technology-mediated TBLT: researching technology and tasks. Amsterdam: John Benjamins. doi:10.1075/tblt.6

Jauregi, K., Canto, S., de Graaff, R., Koenraad, A., \& Moonen, M. (2011). Verbal interaction in Second Life: towards a pedagogic framework for task design. Computer Assisted Language Learning, 24(1), 77-101. doi:10.1080/09588221.2010.538699

Jones, R. (2005). Sites of engagement as sites of attention: time, space and culture in electronic discourse. In S. Norris \& R. Jones (Eds.), Discourse in action: introducing mediated discourse analysis (pp. 144-154). London: Routledge.

Norris, S. (2011). Identity in (inter)action: introducing multimodal (inter)action analysis. Berlin: deGruyter Mouton. doi:10.1515/9781934078280 


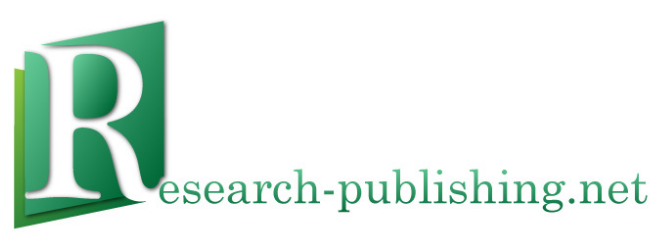

Published by Research-publishing.net, not-for-profit association Dublin, Ireland; info@research-publishing.net

(C) 2015 by Research-publishing.net (collective work)

(C) 2015 by Author (individual work)

Critical CALL - Proceedings of the 2015 EUROCALL Conference, Padova, Italy Edited by Francesca Helm, Linda Bradley, Marta Guarda, and Sylvie Thouësny

Rights: All articles in this collection are published under the Attribution-NonCommercial -NoDerivatives 4.0 International (CC BY-NC-ND 4.0) licence. Under this licence, the contents are freely available online (as PDF files) for anybody to read, download, copy, and redistribute provided that the author(s), editorial team, and publisher are properly cited. Commercial use and derivative works are, however, not permitted.

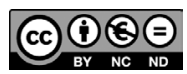

Disclaimer: Research-publishing.net does not take any responsibility for the content of the pages written by the authors of this book. The authors have recognised that the work described was not published before, or that it is not under consideration for publication elsewhere. While the information in this book are believed to be true and accurate on the date of its going to press, neither the editorial team, nor the publisher can accept any legal responsibility for any errors or omissions that may be made. The publisher makes no warranty, expressed or implied, with respect to the material contained herein. While Research-publishing.net is committed to publishing works of integrity, the words are the authors' alone.

Trademark notice: product or corporate names may be trademarks or registered trademarks, and are used only for identification and explanation without intent to infringe.

Copyrighted material: every effort has been made by the editorial team to trace copyright holders and to obtain their permission for the use of copyrighted material in this book. In the event of errors or omissions, please notify the publisher of any corrections that will need to be incorporated in future editions of this book.

Typeset by Research-publishing.net

Fonts used are licensed under a SIL Open Font License

ISBN13: 978-1-908416-28-5 (Paperback - Print on demand, black and white)

Print on demand technology is a high-quality, innovative and ecological printing method; with which the book is never 'out of stock' or 'out of print'.

ISBN13: 978-1-908416-29-2 (Ebook, PDF, colour)

ISBN13: 978-1-908416-30-8 (Ebook, EPUB, colour)

Legal deposit, Ireland: The National Library of Ireland, The Library of Trinity College, The Library of the University of Limerick, The Library of Dublin City University, The Library of NUI Cork, The Library of NUI Maynooth, The Library of University College Dublin, The Library of NUI Galway.

Legal deposit, United Kingdom: The British Library.

British Library Cataloguing-in-Publication Data.

A cataloguing record for this book is available from the British Library.

Legal deposit, France: Bibliothèque Nationale de France - Dépôt légal: décembre 2015. 